\title{
Evaluation of Oil-Based Power Generation of Pakistan. SWOT-Delphi Approach
}

\author{
Sikander Ali Abbasi ${ }^{1,2}$, Khanji Harijan ${ }^{2}$, Irfan Ahmed Abbasi ${ }^{1}$, Ayaz Hussain ${ }^{3}$, \\ ZuhaibuddinBhutto ${ }^{4}$ Syed Ali Raza Shah ${ }^{5}$ \\ ${ }^{1}$ Department of Energy \& Environment Engineering, Dawood University of Engineering \& \\ Technology, Karachi, Pakistan \\ ${ }^{2}$ Department of Mechanical Engineering, Mehran University of Engineering \& Technology, \\ Jamshoro, Pakistan \\ ${ }^{3}$ College of Information and Communication Engineering, Sungkyunkwan University, Suwon, \\ South Korea \\ ${ }^{4}$ Department of Electronic Engineering, Dong-A University, Busan, South Korea \\ ${ }^{5}$ Mechanical Engineering Department, Balochistan University of Engineering and \\ Technology, Khuzdar
}

\begin{abstract}
:
Pakistan is heavily dependent on imported fuel for power generation. Depending on imported fuel has not only increased greenhouse gas emissions (GHG) emissions, but it has also put a burden on the national exchequer and raised apprehensions on energy security. This paper thus investigates the consequences of oil-based power generation on the economy, environment, and energy security of Pakistan. The strength, weakness, opportunity, and threat (SWOT)-Delphi approach has been adopted. The study discovered that the use of imported oil for power generation is detrimental to the economy, environment, and energy security of Pakistan. It further suggests that Pakistan should immediately abandon oil-based power generation and explore green energy alternatives for its sustainable economic growth. This study uses a hybrid model that combines SWOT analysis with the Delphi method.
\end{abstract}

Keywords: oil-based power plants, Pakistan, SWOT analysis, energy security

\section{Introduction}

A third of energy resources in the form of oil, coal, and liquefied natural gas (LNG) is imported by Pakistan. An import-driven power generation policy has not only impacted the national economy but have made the energy mix unsustainable and insecure for Pakistan. Moreover, it has put pressure on foreign exchange reserves, subjected the economy to international energy price shocks, and put the entire economy at risk through inflation. Increased inflation has considerably reduced the competitiveness of the country's exports, further restricting the economy's capacity to pay for energy imports [1]. The import bill of oil costing about 8.4 billion US\$ is $70 \%$ of the total import bill of petroleum products [2]. The major oil exporters in the world with their share are given in Table I [3].

It can be noticed from Table II that the electricity production oil has decreased substantially from $18.7 \%$ in 1975 to $3.28 \%$ in 2015. Energy consumption by oil source in Pakistan has also decreased over the years however, the energy production from oil increased from the year 2005 to 2015 . The 
energy consumption by oil is given in Table III [3].

TABLE I. Countries with largest oil reserves in 2018.

\begin{tabular}{|l|l|l|}
\hline \multicolumn{1}{|c|}{ Country } & $\begin{array}{c}\text { Reserves } \\
\text { (billion barrels) }\end{array}$ & $\begin{array}{l}\text { Share } \\
(\boldsymbol{\%})\end{array}$ \\
\hline Venezuela & 303 & 18 \\
\hline Saudi Arabia & 298 & 17 \\
\hline Canada & 167 & 10 \\
\hline Iran & 156 & 9 \\
\hline Iraq & 147 & 9 \\
\hline Russia & 106 & 6 \\
\hline Kuwait & 102 & 6 \\
\hline UAE & 98 & 6 \\
\hline USA & 61 & 4 \\
\hline Libya & 48 & 3 \\
\hline
\end{tabular}

TABLE II. World share of electricity from oil (1975- 2015) [4]

\begin{tabular}{|c|c|}
\hline Year & \% of total \\
\hline 1975 & 18.7 \\
\hline 1980 & 15.7 \\
\hline 1985 & 9.1 \\
\hline 1990 & 10.2 \\
\hline 1995 & 8.4 \\
\hline 2000 & 7.3 \\
\hline 2005 & 5.75 \\
\hline 2010 & 3.8 \\
\hline 2015 & 3.28 \\
\hline
\end{tabular}

TABLE III. Electricity consumption by oil (1970-2019)

\begin{tabular}{|l|l|l|l|}
\hline Year & $\begin{array}{c}\text { Total } \\
\text { electricity } \\
\text { consumpt } \\
\text { ion } \\
\text { (TWh) }\end{array}$ & $\begin{array}{c}\text { Consum } \\
\text { ption by } \\
\text { oil } \\
\text { (TWh) }\end{array}$ & $\begin{array}{c}\text { Share of } \\
\text { electricity } \\
\text { consumpt } \\
\text { ion by oil } \\
(\%)\end{array}$ \\
\hline 1970 & 102 & 54 & 52.9 \\
\hline 1980 & 153 & 60 & 39.2 \\
\hline 1990 & 302 & 128 & 42.3 \\
\hline 2000 & 480 & 223 & 46.0 \\
\hline 2010 & 736 & 244 & 33.0 \\
\hline 2019 & 989 & 251 & 25.3 \\
\hline
\end{tabular}

Pakistan is the sixth populous country in the world and its annual population growth rate is $2 \%$ per year. In [5], with moderate GDP, urbanization, industrialization, and an increase in per capita income, electricity consumption increased substantially in the last two decades.
The annual growth rate in electricity consumption is $3.8 \%$ [6]. In addition to it, electricity consumption growth rate of domestic, commercial, agriculture, industry and others remained $6.5 \%, 6.4 \%, 1.5 \%, 1.9 \%$, and $6.25 \%$ respectively [7]. The electricity growth rate is $10 \%$ annually while the capacity addition is 7\% only [8]. Findings of one study suggest that at a global level, energy for economic development, energy security, and climate change mitigation be perused as integrated themes since there are linkages among these three agendas [9]. Various governments in Pakistan could not anticipate the increase in electricity demand, resultantly Pakistan witnessed a shortfall of around 5000 MW of electricity over the last decade. The slow generation capacity addition was due to shortsightedness, financial constraints, and delayed policies on implementation levels [10]. However, Pakistan encouraged the private sector to invest in the power sector which resulted in a considerable increase in power generation capacity. Though the gap between supply and demand is over however due to shortage of indigenous natural gas, nonpayment of dues to Independent Power Producers (IPPs), the country continues to suffer from load shedding. The shortfall in the last decade hindered the economic development in terms of closure of industries, unemployment of 0.535 million people, $2.5 \%$ of GDP loss, and loss of export of about 1.3 billion US dollars. Dependence on imported fossil fuels has not only increased the cost of the generation, but it has also led to increase in greenhouse gas (GHG) emissions and made country susceptible to energy insecurity. To meet the electricity demand adequately, the first power policy was announced in 1994. The main features of policy are given as:

- Private parties could propose a site, choice of technology, and fuel type to be used for generating plants.

- Water and Power Development Authority (WAPDA) and K-Electric were made bound to buy power from Independent Power Producers (IPPs) under the long-term purchase agreements. 
- Upfront bulk power tariff was introduced for private investors.

- For thermal power plants, built-onoperate (BOO) was followed.

- Draft security agreement was made flexible by the government of Pakistan.

- Guaranteed availability of foreign exchange.

- The $40 \%$ of capital cost shall be made available by the government of Pakistan.

The core objective of this power policy was to attract IPPs in the electricity sector of Pakistan. Power policy 1994 framework predominantly resulted in private investment in oil and gas-fired power plants mainly based on imports. This policy framework provided almost blanket exemptions from all duties and taxes [11]. The root cause of the crisis could be traced back to the power policy of 1994 which significantly altered the electricity mix in subsequent years [12]. The above power policy indicates that the IPPs took advantage of incentives and commissioned power plants based on imported fuels. The upward trend of oil price in the international market has damaged the economies of developing countries including Pakistan. The rising trend of oil prices slow down the GDP, increased inflation, and affected the balance of payments. The direct result of high oil prices on an economy is realized through the worsening of payments and resultant shrinking of the economy [13]. The fundamental factor responsible for the electricity crisis in Pakistan is its increased reliance on imported furnace oil and lack of diverseness in the electricity generation mix. The higher dependence on furnace oil is responsible for the increased cost of generation due to expensive imported fuel [14]. Even in subsequent power policies, expediency was given priority over sustainability. To meet increased electricity demand, thermal power plants were commissioned, and it was assumed as an immediate solution to the energy crisis. Globally use of oil for power generation has decreased due to its price uncertainty, uncertain availability due to the geopolitical situation, and environmental implications. In this backdrop, the evaluation of oil-based power generation has been undertaken considering three parameters namely energy security, economic viability, and environmental sustainability. Since these three parameters are prominent in the literature and are closely interconnected with each other therefore these have been considered. Various studies have defined these themes in the literature however most prominent definitions are explained in the subsequent paragraph. One such study has defined energy security as an adequate and reliable supply of energy resources at a reasonable price [1]. As per the definition of the International Energy Agency (IEA), energy security is "uninterrupted availability of energy sources at an affordable price". Economic viability is an evaluation of various economic effects that may result from the implementation of a particular project. According to the United Nations (UN), World Commission on Environment and Development environmental sustainability is about acting in a way that ensures future generations have the natural resources available to live an equal, if not better, way of life as current generations [15]. The theme 'environmental sustainability is also defined as "managing energy and resources to minimize the environmental and ecological impacts of human activities now and for future" Many studies have evaluated the power generation methods and their impact on the economy, energy security, and environmental sustainability. Limited literature is available on power generation evaluation with SWOT globally. Few studies have also been undertaken on the power generation sector in Pakistan. In [16], the authors reviewed and assessed the factors of strengths, weaknesses, opportunities, and threats of biomass power generation of China. They used statistical reports literature review regulation policies and case studies. With SWOT analysis, they provided valuable information to devise future development and potential risks associated with biomass power. In [17], they used an approach of SWOT analysis by investigating internal strengths, weaknesses, opportunities, 
and threats for the photovoltaic solar development of Africa. The authors identified that Africa has a great potential to exploit solar energy with the cooperation of China and international cooperation within the framework of the Belt and Road initiative (BRI). In [18], the authors assessed the challenging outlooks for energy mix in the Association of Southeast Asian Nations (ASEAN) stressing the impact of fossil fuel dominated outlook when compared with its ambition to move toward green energy policies using strengths, weaknesses, opportunities, and threats. The author argues that despite the brown look due to the growing surge of coal, the ASIAN region has many advantages in offering cleaner and greener energy for its green vision. For this target to achieve, the countries need to make further efforts to promote renewable energy, energy efficiency, regional market integration, and connectivity. Author links open overlay panel. In [19], the authors conducted SWOT analysis for Turkey's energy sector and anticipated an integrated hybrid methodology using strengths, weaknesses, opportunities, and threats (SWOT) analysis, Analytic Network Process (ANP), and weighted fuzzy techniques for order performance by similarity and holistically examined the energy strategy substitutes and priorities. The technique recommended in this study allowed identifying relevant criteria and sub-criteria using SWOT analysis. In [20], the authors conducted a SWOT analysis of nuclear power electricity generation. He concluded that nuclear power generation along with other renewable energies is a viable option to reduce greenhouse gases. He further concluded that fossil-fueled power plants should be integrated with Carbon Capture and Storage (CCS) technology. In [21] the authors discussed Canada's federal and provincial government's coherence while implementing the climate and energy policies. They tried to identify the prospects and challenges of energy policy in implementation with SWOT analysis. In [22], the authors identified the positive and negative aspects of deploying nuclear energy in Nigeria with a SWOT matrix. The authors reviewed Nigeria's venture into nuclear energy while considering global efforts towards nuclear security and safety. They concluded that nuclear energy can be harnessed in Nigeria while maintaining global safety practices.

In Pakistan, SWOT studies on the power generation sector are few which are mainly focused on renewable energy. In [23], the authors conducted SWOT analysis of renewable energy of provinces of Sindh and Baluchistan of Pakistan. Fuzzy Analytical Hierarchy Process (Fuzzy AHP) has also been used. Three renewable resources (wind, solar, and biomass) have been assessed as alternatives in the decision model. They found that economic and sociopolitical are the two most important criteria. They concluded that wind has ample potential to generate electricity in both provinces. In [24], the authors performed a SWOT analysis of renewable energy in Pakistan. Authors pinpointed that huge resource potential and renewable energy maps are the strengths, while poor institutional infrastructure is its weakness. The untapped potential, micro, and mini installation are few opportunities. The threats to renewable energy are the presence of competitive energy resources, policy implications, and grid connection. Finally, they concluded that retainability of renewable energy is necessary for energy security and sustainability for Pakistan's power sector, such as significant advancement to attain energy security and sustainability. In [25], the authors reviewed the issues of the power generation sector in general, the role of renewable energy in the overall mix and very precisely touched the sustainable pathway with SWOT analysis. They summarized that Pakistan has sizable reserves of coal and the opportunity to develop gas infrastructure, inefficient utilization of domestic resources, high transmission and distribution losses have been regarded as a weakness in the system. Authors have pinpointed the opportunities of distributed generation and smart grid. They concluded that to protect from threats, Pakistan must reduce reliance on excessive imported fuel and reduce the cost of unit generation of power. From the above studies, it is noticed that no such study on the evaluation of oil-based power generation has been undertaken in Pakistan. 
Secondly, this study has quantitatively evaluated the drivers and barriers of oil-based power generation with the RII analysis tool. This approach has enabled us to quantify the most prominent positive and negative parameters responsible for oil-based power generation. However, the decision-makers are required to consider a substantial amount of data concerning the internal strengths and weaknesses of the oil-based power generation methods as well as external opportunities and threats. The method and results of this study could be useful for future energy policies within Pakistan and other countries with similar energy demand patterns. The organizational structure of this paper is such that methodology is given in Section 2. The results and discussion part are explained in Section 3. Conclusions and policy implications are narrated in Section 4.

\section{Methodology}

\subsection{Delphi- SWOT Paradigm}

From the above discussion, it is evident that Pakistan faces both merits and demerits in balancing its future energy mix. With capacity constraints and an uncertain sociopolitical environment, the emerging electricity generation scenario is not clear. The SWOT analysis of Pakistan's power generation was accompanied by the Delphi approach. Delphi's approach is well suited for consent building. Delphi's approach helps in reaching a consensus on critical issues in a diverse environment. It is a process to decide on any ambiguous topic based on a survey of respondent's judgment. The procedure was adopted in the Delphi method during the study is given as:

- Draft security agreement was made flexible by the government of Pakistan.

- Experts from the oil-based power generation source were first identified and requested to take part in the survey.
Experts were middle and senior managerial persons who had an adequate understanding of oil-based power generation methods.

- The Delphi statements were developed by the authors and pursued through various successive questionnaires.

- Experts were requested to give their opinion on the strengths, weaknesses, opportunities, and threats of the oilbased power generation method.

- The range of participant's opinions has been identified by the Likert Scale.

- The extreme opinions were reevaluated by the participants in the second round.

Lastly, a SWOT strategy was formulated before the proper evaluation of the oil-based power generation. Questionnaires were delivered in two rounds using multiple iterations to collect data from a panel of the selected field. The expert's assessment was weighted by the Likert Scale. In this study, the Likert scale was judged from 1 to 5 points as given in Table IV [28]. Each point's comment was recorded. The expert's opinion in the field of strengths, weaknesses, opportunities, and threats was calculated in descending order based on the expert's weighted evaluation.

TABLE IV. Likert scale rating

\begin{tabular}{|l|l|}
\hline \multicolumn{1}{|c|}{ Point } & Remarks \\
\hline 1 & Strongly disagree \\
\hline 2 & Disagree \\
\hline 3 & Neutral \\
\hline 4 & Agree \\
\hline 5 & Strongly agree \\
\hline
\end{tabular}

The mostly, respondents were from academia followed by government organizations and research institutions as shown in Fig. 1. 


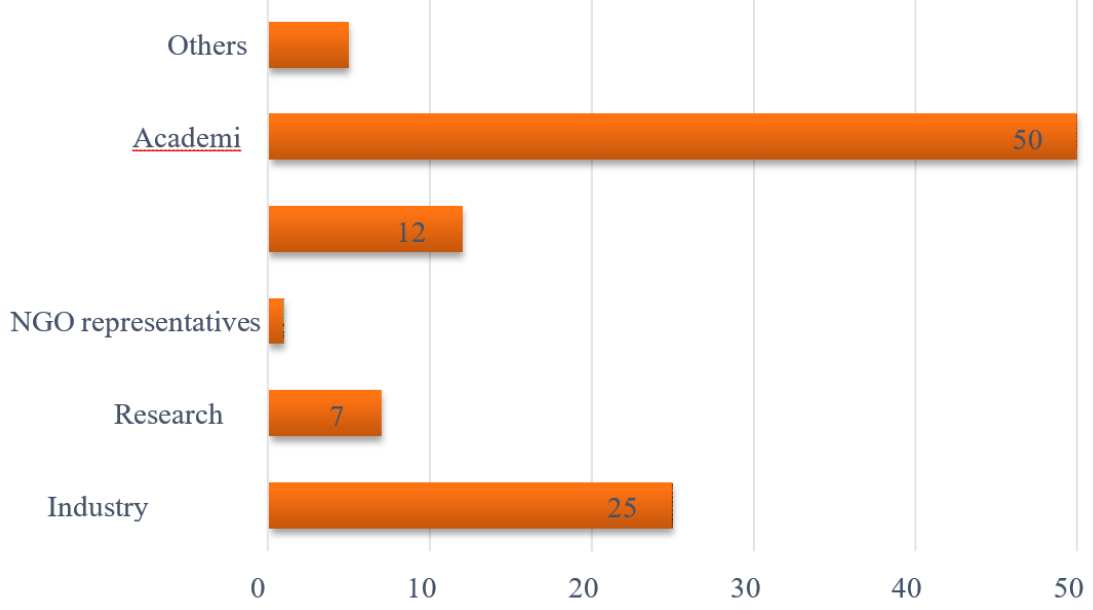

Fig. 1. Distribution of the Delphi survey participants according to their significance

The feedback regarding the weightage of anticipated issues was collected by sending questionnaires online in two rounds. The names of experts were kept confidential as per the understanding before sending the questionnaire to them. The number of experts for the oil-based power generation method was varying depending on the accessibility of experts. They were contacted to reply to the questionnaire in two rounds. The response was diverse. The overall response was encouraging. Based on the response received, the average of each parameter and an overall average of strengths, weaknesses, opportunities, and threats were calculated with the Relative Importance Index (RII) tool. The number of respondents contacted for each resource and their response is given in Table V. The SWOT investigation of oil-based power generation is given in Fig 2 and discussion of strength, weakness, opportunities and threats are presented in Section 3. Three major themes have been considered in SWOT as shown in Fig. 3. As per the definition of International Energy Agency (IEA), the term energy security is defined as uninterrupted availability of energy sources at an affordable price. Economy is the second theme of this study which relates with cost of production and consumption of electricity. The environmental sustainability is the management of energy and resources to minimize the environmental and ecological impacts of human activities now and for future.

TABLE V. Generation sources with a response rate of experts

\begin{tabular}{|l|l|c|c|}
\hline $\begin{array}{l}\text { Power } \\
\text { generatio } \\
\text { n source }\end{array}$ & $\begin{array}{l}\text { Number } \\
\text { of experts } \\
\text { contacted }\end{array}$ & $\begin{array}{c}\text { Number } \\
\text { of experts } \\
\text { replied }\end{array}$ & $\begin{array}{c}\text { Respon } \\
\text { se rate } \\
(\%)\end{array}$ \\
\hline Oil & 60 & 50 & 83 \\
\hline
\end{tabular}

\subsection{SWOT Analysis}

SWOT analysis permits better-structured qualitative analysis of the predefined issue, second, SWOT is a strategic analysis tool aimed to improve the system. Hence it is more vibrant and therefore better able to identify potential revisions that improve policy strategy.

The consistency of a policy can be verified by SWOT that involves several parallel objectives. At the same time, SWOT analyses have several limitations. SWOT analysis is often subjective even if the analysis is well structured and an agreement about its findings may be hard to attain. Moreover, even if it allows us to understand the strategic axis of a policy with many objectives and complicated expected impacts, it streamlines the real problem. 


\begin{tabular}{|l|}
\hline STRENGTH \\
- Decades of experience \\
- Strong network of man power \\
- Less initial cost \\
- Base load power plant \\
- High power density \\
\hline WEAKNESSES \\
\hline - Higher dependence on imported oil \\
- Lack of energy audit \\
- Price vulnerability \\
- 37\% of global GHG emission is from power industry. \\
\hline OPPORTUNITIES \\
- Strong Potential to invest in R\&D. \\
- Up gradation of existing infrastructure \\
- International cooperation \\
- Policies that promote energy efficiency technologies leading to job \\
creation \\
\hline THREATS \\
\hline - Cost of transportation of oil \\
- Geopolitical instability \\
- circular debt \\
- high import bill \\
- Restrictions owing to GHG emissions \\
\hline
\end{tabular}

Fig. 2. SWOT Investigation

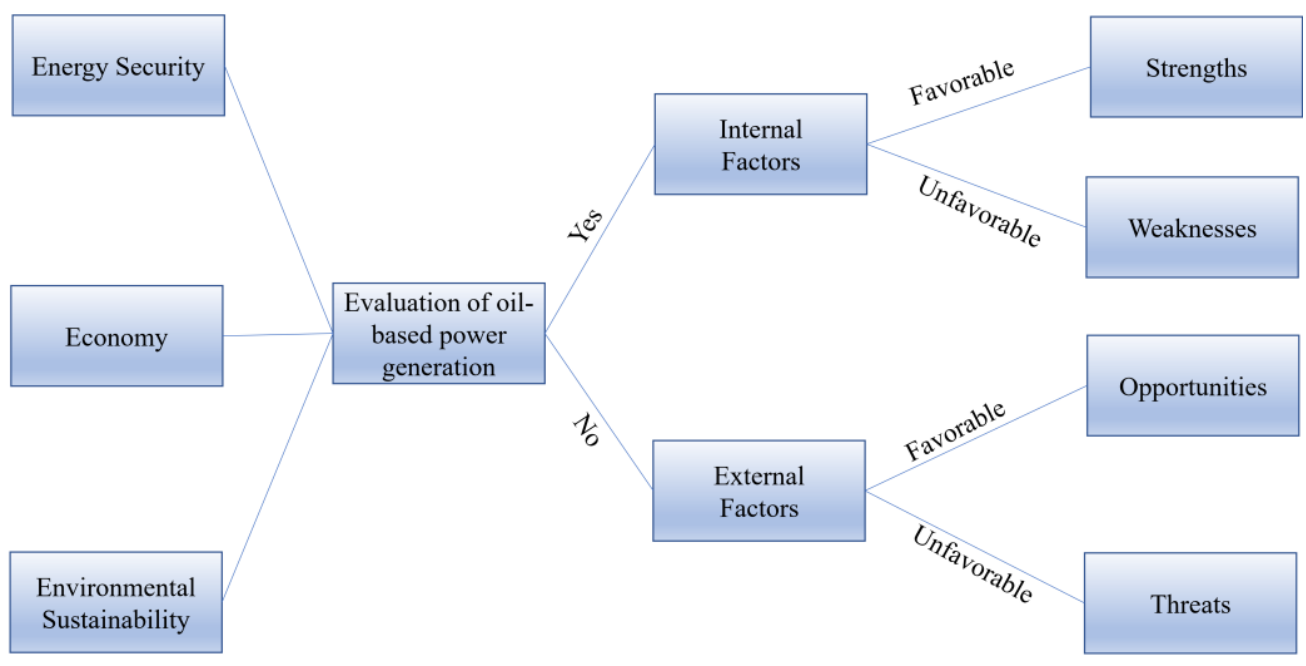

Fig. 3. SWOT Synthesis 
It is important to define external and internal factors before the SWOT analysis is done. Moreover, SWOT analysis is an approach allowing an industry or organization to comprehend and plan to use their strengths to exploit opportunities to recognize and mend or prevent their weaknesses and to protect against any unknown threats. Since Pakistan still relies on the imported oil for the generation therefore, SWOT analysis with Delphi and RII analysis of oil-based power generation method has been conducted.

\subsection{Relative Importance Index Analysis}

Relative Importance Index (RII) analysis tool is used to highlight the most important attributes. RII analysis allows identifying the most important criteria based on participant's replies and it is also an appropriate tool to prioritize indicators rated on the Likert scale. Each point's remark is put in the RII equation. The RII method was adopted in this study to determine the relative importance of various factors affecting the quality of attributes.

The formula of RII in the literature is

$R I I=\frac{\sum W}{A * N} \frac{(5 n 5+4 n 4+3 n 3+2 n 2+1 n 1)}{5 * N}$

where $\mathrm{W}=$ weighting given to by respondents (ranging from 1 to 5); $A=$ highest weight (i.e., 5 in this case) and $N=$ total number of respondents.

\subsection{Average RII Analysis}

From the analysis of RII, it is found that the threats have got highest point and opportunities have lowest point as shown in Fig. 4, which proves that oil-based power generation is not suitable for Pakistan.

\section{Results and Discussion}

\subsection{Strengths}

- Decades of experience $\rightarrow$ Oil-based thermal power plants were commissioned in Pakistan after the announcement of the energy power policy of 1994. More oil-based power plants were added to the energy mix of Pakistan in later years by Independent Power Producers (IPPs). Therefore, the country has sound experience of running these plants proficiently. The operational and maintenance issues are addressed satisfactorily. The sound knowledge and skills provide greater strengths to the successful running of such power plants.

- $\quad$ A strong network of manpower $\rightarrow$ Since oil-based power plants are old in Pakistan, therefore the human resource-related with this sector has profound experience and skills to tackle routine problems of oil-based power plants. The training and special sessions are also conducted at certain intervals of time therefore, there is a reasonable number of trained staff available across the country. This provides the strength to run these plants without any difficulty.

- $\quad$ Less initial cost $\rightarrow$ The initial cost of oil-based thermal power plants is less as compared to hydro and nuclear plants. Hence these plants are preferred over other conventional plants when the capital cost is of paramount importance. Secondly, these plants take less time to complete therefore, Pakistan opted for these plants owing to an acute shortage of electricity over the last decade.

- $\quad$ Baseload plants $\rightarrow$ These plants can take up load on the base portion of the load curve of the power system. They are generally of large capacity. These plants run practically on block load, i.e. load that is practically constant. The load factor of these plants is high. Therefore, these plants always ensure the minimum electricity supply to consumers hence ensures the reliability of the power supply in the system.

TABLE VI. RII analysis of oil based power generation 


\begin{tabular}{|c|c|c|c|c|c|c|c|c|}
\hline & $\begin{array}{c}\text { Strongly } \\
\text { Disagree } \\
\text { (1) }\end{array}$ & $\begin{array}{c}\text { Disagree } \\
\text { (2) }\end{array}$ & $\begin{array}{c}\text { Neutral } \\
\text { (3) }\end{array}$ & $\begin{array}{c}\text { Agree } \\
\text { (4) }\end{array}$ & $\begin{array}{l}\text { Strongly } \\
\text { Agree (5) }\end{array}$ & $\begin{array}{c}\text { No. of } \\
\text { Respo } \\
\text { ndents }\end{array}$ & RII & $\begin{array}{c}\text { RII } \\
\text { (AVG) }\end{array}$ \\
\hline $\begin{array}{ll}\begin{array}{l}\text { Decades } \\
\text { experience }\end{array} & \text { of }\end{array}$ & 4 & 4 & 8 & 24 & 10 & 50 & 0.728 & \multirow{5}{*}{0.8} \\
\hline $\begin{array}{l}\text { Strong network } \\
\text { of manpower }\end{array}$ & 4 & 4 & 10 & 24 & 8 & 50 & 0.712 & \\
\hline Less initial cost & 0 & 2 & 8 & 24 & 16 & 50 & 0.81 & \\
\hline $\begin{array}{l}\text { Base load } \\
\text { power plant }\end{array}$ & 0 & 0 & 4 & 16 & 30 & 50 & 0.90 & \\
\hline $\begin{array}{ll}\text { High } & \text { power } \\
\text { density }\end{array}$ & 0 & 0 & 8 & 12 & 30 & 50 & 0.88 & \\
\hline
\end{tabular}

\begin{tabular}{|c|c|c|c|c|c|c|c|c|}
\hline \multicolumn{9}{|c|}{ Weaknesses } \\
\hline & $\begin{array}{c}\text { Strongly } \\
\text { Disagree } \\
\text { (1) } \\
\end{array}$ & $\begin{array}{c}\text { Disagree } \\
\text { (2) }\end{array}$ & $\begin{array}{c}\text { Neutral } \\
\text { (3) }\end{array}$ & $\begin{array}{l}\text { Agree } \\
\text { (4) }\end{array}$ & $\begin{array}{l}\text { Strongly } \\
\text { Agree (5) }\end{array}$ & $\begin{array}{l}\text { No. of } \\
\text { Respo } \\
\text { ndents }\end{array}$ & RII & $\begin{array}{c}\text { RII } \\
(\text { AVG) }\end{array}$ \\
\hline $\begin{array}{l}\text { High } \\
\text { dependence on } \\
\text { imported oil }\end{array}$ & 4 & 4 & 8 & 24 & 10 & 50 & 0.728 & \multirow{5}{*}{0.8} \\
\hline $\begin{array}{l}\text { Lack of energy } \\
\text { audit }\end{array}$ & 4 & 4 & 10 & 24 & 8 & 50 & 0.712 & \\
\hline $\begin{array}{l}\text { Price } \\
\text { vulnerability }\end{array}$ & 0 & 2 & 8 & 24 & 16 & 50 & 0.81 & \\
\hline $\begin{array}{l}37 \% \text { of global } \\
\text { GHG emission } \\
\text { is from the } \\
\text { power industry. }\end{array}$ & 0 & 0 & 4 & 16 & 30 & 50 & 0.90 & \\
\hline $\begin{array}{l}\text { High power } \\
\text { density }\end{array}$ & 0 & 0 & 8 & 12 & 30 & 50 & 0.88 & \\
\hline
\end{tabular}

\begin{tabular}{|c|c|c|c|c|c|c|c|c|}
\hline \multicolumn{9}{|c|}{ Opportunities } \\
\hline & $\begin{array}{c}\text { Strongl } \\
y \\
\text { Disagre } \\
\text { e (1) }\end{array}$ & $\begin{array}{c}\text { Disagree } \\
\text { (2) }\end{array}$ & $\begin{array}{c}\text { Neutral } \\
\text { (3) }\end{array}$ & $\begin{array}{l}\text { Agree } \\
\text { (4) }\end{array}$ & $\begin{array}{l}\text { Strongly } \\
\text { Agree (5) }\end{array}$ & $\begin{array}{l}\text { No. of } \\
\text { Respon } \\
\text { dents }\end{array}$ & RII & $\underset{\text { (AVG) }}{\text { RII }}$ \\
\hline $\begin{array}{l}\text { Strong Potential } \\
\text { to invest in } \\
\text { R\&D }\end{array}$ & 4 & 6 & 16 & 14 & 10 & 50 & 0.728 & \multirow{4}{*}{0.68} \\
\hline $\begin{array}{l}\text { Up gradation of } \\
\text { existing } \\
\text { infrastructure }\end{array}$ & 2 & 6 & 14 & 16 & 12 & 50 & 0.712 & \\
\hline $\begin{array}{l}\text { International } \\
\text { cooperation }\end{array}$ & 4 & 14 & 16 & 12 & 4 & 50 & 0.81 & \\
\hline $\begin{array}{l}\text { Policies that } \\
\text { promote energy } \\
\text { efficiency } \\
\text { leading to job } \\
\text { creation }\end{array}$ & 2 & 4 & 12 & 20 & 12 & 50 & 0.90 & \\
\hline
\end{tabular}


Sikander Ali Abbasi (et al.), Evaluation of Oil-Based Power Generation of Pakistan. SWOT-Delphi Approach

\begin{tabular}{|c|c|c|c|c|c|c|c|c|}
\hline \multicolumn{9}{|c|}{ Threats } \\
\hline & $\begin{array}{c}\text { Strongl } \\
y \\
\text { Disagre } \\
\text { e (1) }\end{array}$ & $\begin{array}{c}\text { Disagree } \\
\text { (2) }\end{array}$ & $\begin{array}{c}\text { Neutral } \\
\text { (3) }\end{array}$ & $\begin{array}{l}\text { Agree } \\
\text { (4) }\end{array}$ & $\begin{array}{l}\text { Strongly } \\
\text { Agree (5) }\end{array}$ & $\begin{array}{c}\text { No. of } \\
\text { Respon } \\
\text { dents }\end{array}$ & RII & $\begin{array}{c}\text { RII } \\
\text { (AVG) }\end{array}$ \\
\hline $\begin{array}{l}\text { Cost of } \\
\text { transportation of } \\
\text { oil }\end{array}$ & 0 & 0 & 10 & 20 & 20 & 50 & 0.84 & \multirow{5}{*}{0.84} \\
\hline $\begin{array}{l}\text { Geopolitical } \\
\text { instability }\end{array}$ & 0 & 0 & 10 & 20 & 20 & 50 & 0.84 & \\
\hline Circular debt & 0 & 0 & 10 & 20 & 20 & 50 & 0.84 & \\
\hline High import bill & 0 & 0 & 6 & 24 & 20 & 50 & 0.85 & \\
\hline $\begin{array}{l}\text { Restrictions } \\
\text { owing to GHG } \\
\text { emissions }\end{array}$ & 0 & 0 & 5 & 10 & 10 & 50 & 0.84 & \\
\hline
\end{tabular}

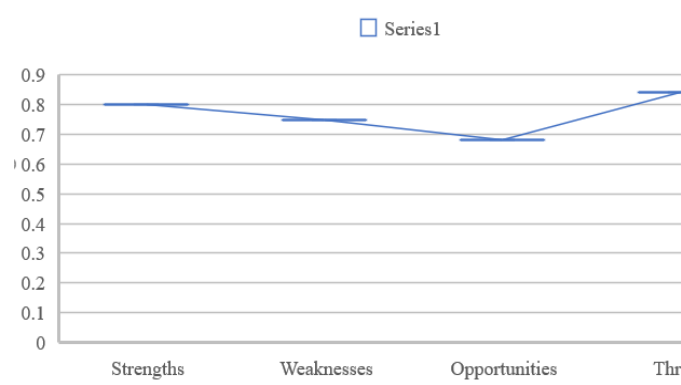

Fig. 4. Average points through RII analysis

High power density $\rightarrow$ These plants are large with high capacity. Therefore, such plants are commissioned when electricity demand is high, and the reliability of supply is not compromised under any circumstances. Since these power plants cover the base portion of the load curve, hence these plants ensure the continuous supply of power to their consumers.

\subsection{Weaknesses}

- Higher dependence on imported oil $\rightarrow$ Higher dependence on imported oil makes power generation unsustainable. The uninterruptable oil supply is a prerequisite for a reliable supply of power to its consumers. However, the oil supply is always subjected to the external economic and political situation. Moreover, the supply can be disrupted in case of any eventuality or natural catastrophe. This uncertainty causes compromise on the smooth supply of fuel, leading to disruption of power generation.

- $\quad$ Lack of energy audit $\rightarrow$ A regular energy audit is regarded as the most important feature of any efficient industry. An energy audit identifies the weaknesses in the system thus paving the way for remedial measures to increase efficiency. However, Pakistan's power sector has underinvested in this area and no robust energy audit program is in place. Also, management lacks motivation. As a result of lack of motivation and underinvestment, the efficiency of plants is highly compromised. With inefficient plants, the cost of electricity units also increases thus making the power supply unaffordable and unsustainable.

- $\quad$ Price vulnerability $\rightarrow$ Since furnace oil is imported, therefore Pakistan has no control over the price of fuel. Any fluctuation in price is caused by the international dynamics of the oil industry. As per the agreement between regulator and IPPs, the IPPs supply power on a cost-plus basis thus its adverse impacts result in the form of an increase in perunit cost of electricity. This increase in per-unit cost is partially borne by the government in the form of subsidies and by consumers. Therefore, the cost fluctuation of oil always puts pressure on the national exchequer and consumers.

- $\quad 37 \%$ of GHG emissions are from the power industry $\rightarrow$ Power plants are major 
contributors to GHG emissions around the globe. Among them, conventional thermal power plants are mainly responsible for GHG emissions. Besides GHG emissions, these plants emit toxic gases such as SOx. Since these plants are not considered environmentally friendly, therefore new oilbased power plants are being discouraged around the globe and the share of oil-based power plants is left with only $7 \%$ of the total energy mix. Thus, environmental sustainability is compromised with the presence of oil-based power plants.

\subsection{Opportunities}

\section{- Up-gradation} of existing infrastructure $\rightarrow$ Since most oil-based power plants are old in Pakistan and without any effective energy audit program in place, therefore the plants are running on low efficiency. As a result, the cost of power produced is high along with environmental consequences. Modern thermal power plants run on supercritical technology with control on environmental emissions, therefore old power plants badly need retrofitting to bring them at par with new plants. This provides an opportunity for old power plants to become more efficient, and environmentally more sustainable.

- International cooperation $\rightarrow$ Many countries have retrofitted their conventional old power plants successfully with a profound increase in energy efficiency and controlled environmental pollution from their stacks. Therefore, there is a need to learn from the experiences of other countries. With the retrofitting approach, Pakistan can increase the efficiency of its oil-based thermal power plants with a substantial decrease in environmental pollution.

- Policies, that promote energy efficiency technologies leading to job creation $\rightarrow$ Energy efficiency measures have pronounced benefits in the overall operations of oil-based thermal power plants. Since Pakistan's thermal power plants are old, therefore this sector has enormous opportunities to enhance efficiencies. Energy efficiency measures will reduce the cost of power produced, thus relieving financial pressure on government and consumers. Secondly, pollution is reduced with an increasing inefficiency. Therefore, Pakistan's thermal power generation has an enormous opportunity to promote energy efficiency. Investing in this area will also create job opportunities.

\subsection{Threats}

- Geopolitical instability $\rightarrow$ Pakistan imports furnace oil from the kingdom of Saudi Arabia. Saudi Arabia is situated in an area, which has become a war zone. Yemen war has jeopardized the oil installations of the kingdom. Yamane rebel's attack on Saudi oil facilities has exposed the vulnerability of oil supply to importers including Pakistan. A recent attack of rebels on Saudi oil installations disrupted $50 \%$ oil supply in a day. Rising tension between Iran and Saudi Arabia has threatened the oil supply from refineries to its suppliers. In case of war between the two countries, the oil supply would directly hit Pakistan and can pose considerable economic and electricity reliability risks.

- $\quad$ Circular debt $\rightarrow$ The circular debt has emerged as a great threat to the reputation, credit rating, and economic stability of the country. It is hitting industrial development, investment in indigenous resources like coal and other energy-related projects and discouraging investors while it is leaving IPPs unable to buy fuel or repay bank loans. The menace of circular debt can only be wiped out sustainably only when system inefficiencies, mismanagement, and line losses are addressed along with penetration of hydro and other renewable energy sources in the energy mix of Pakistan.

- $\quad$ High import bill $\rightarrow$ Pakistan spends 12 billion US dollars annually on the import of crude oil. $70 \%$ of oil is used in generating power costing PRs 18 per unit. With limited resources and spending such a huge amount on oil import for power generation is a great threat to the economic stability of the country. 
Moreover, the cost of power production goes high and becomes highly uncompetitive.

- Restrictions owing to GHG emissions $\rightarrow$ Out of total GHG emissions, the share of $\mathrm{CO}_{2}$ emission from the power sector is $50 \%$ [27]. In 2016, the $\mathrm{CO}_{2}$ emissions were 155.27Mt of $\mathrm{CO}_{2}$ [28]. Being the signatory of international climate protocols, Pakistan must comply with international agreements. Unchecked GHG emissions can put penalties in the future which will increase externality costs. Therefore, Pakistan will have to phase out oil-based thermal power plants to enhance the sustainability of the overall power generation sector.

\section{Conclusion and Policy Implications}

Based on the SWOT-Delphi model and the RII analysis as given in Table VI, it is found that despite the established infrastructure of oilbased power generation, Pakistan's economy, energy security, and environmental sustainability are vulnerable. From the RII analysis, it is also evident threats with 0.84 points are more than the strengths with 0.8 points. The main threats are circular debt, geopolitical instability, high import bill, and GHG emissions. With these shortcomings alongside heavy borrowing from international banks and agencies, the country suffers from direct foreign investment in the power sector. Therefore, the country needs to revisit its energy policies to attain energy security and environmental sustainability.

Pakistan will continue to suffer from chaos and uncertainty in the power sector unless some concrete steps in addition to the above are taken as stated below.

- Renewable energy technologies must be penetrated in the energy mix of Pakistan.

- There is a need to upgrade the infrastructure of the power system.

- The highest priority is given to the privatization of distribution companies.

- An effective energy efficiency policy may be implemented.
- Utilization of indigenous coal with High Efficiency and Low Emission (HELE) technologies for electricity production.

- There is a need to minimize transmission and distribution losses.

- A culture of energy conservation may be introduced in all sectors. According to ENERCON, there is a $17 \%$ saving potential of energy.

- Bringing the energy sector under a single managing authority will bring about significant improvement in the system.

- There is a need to learn from the experiences of other countries.

- Reduction of losses through a microgrid and smart grid may be initiated.

- The utilization of the potential of Pakistan Shell gas reserves (105 TCF) can also be a positive move. Pakistan has Shell Oil reserves (9.1 Billion Barrels). This is a viable option for Pakistan.

- Integrated energy modeling and planning mechanism needs to be incorporated into a policy framework.

- Development of integrated GIS framework for the energy sector.

Therefore, there is an urgent need to take the above steps to shape the power sector in such a way that ensures sustained economic growth, energy security, and environmental sustainability.

\section{DATA AVAILABILITY STATEMENT}

We state that we have not taken data from any database. This data is taken from a field survey. This data is available in the directorate of postgraduate studies, Mehran University of Engineering \& Technology, Jamshoro.

\section{AUTHOR CONTRIBUTION}

All authors contributed equally to the work. 


\section{CONFLICT OF INTEREST}

The authors declare no conflict of interest.

\section{FUNDNG}

Not applicable

\section{ACKNOWLEDGMENT}

The authors are highly indebted to their respective Universities to provide all assistance and resources to complete this work.

\section{REFERENCES}

[1] S. Malik, M. Qasim, H. Saeed, Y. Chang, F. T. Hesary, "Energy Security in Pakistan: A quantitative approach to a sustainable energy policy", no. 1024, pp. 75-75, 2019.

[2] A. Z. K. Aziz, S., Burki, S. J., Ghaus-Pasha, A., Hamid, S., Hasan, P., Hussain, A., \& Sherdil, "Third Annual Report-State of the Economy: Pulling back from the abyss", 2010.

[3] BP, "Statistical Review of World Energy globally consistent data on world energy markets and authoritative publications in the field of energy The Statistical Review world of World Energy and data on world energy markets from is The Review has been providing", p. 66, 2020.

[4] IEA, "International Energy Agency (IEA)", 2014.

[5] H. Qudrat-Ullah, "Independent power (or pollution) producers? Electricity reforms andIPPs in Pakistan", Energy, vol. 83, pp. 240-251, 2015.

[6] E. Y. Book, "Primary Energy Mix", Encycl. Corp. Soc. Responsib., pp. 1892-1892, 2013.

[7] HDIP, "Hydrocarbon Development Institute of Pakistan: Islamabad". 2017.

[8] M. M. Rafique, S. Rehman, "National energy scenario of Pakistan - Current status, future alternatives, and institutional infrastructure: An overview", Renew. Sustain. Energy Rev., vol. 69, no. November 2016, pp. 156-167, 2017.

[9] T. H. L. P. Nguyen, "Is energy security a driver for economic growth? Evidence from a global sample", Energy Policy, vol. 129, no. February, pp. 436-451, 2019.

[10] T. Aized, M. Shahid, A. A. Bhatti, M. Saleem G. Anandarajah, "Energy security and renewable energy policy analysis of Pakistan", Renew. Sustain. Energy Rev., vol. 84, no. September 2016, pp. 155-169, 2018.
[11] Government of Pakistan, "Policy framework and package of incentives for private sector power generation projects in Pakistan". pp. 122, 1994.

[12] H. Ishaque, "Is it wise to compromise renewable energy future for the sake of expediency? An analysis of Pakistan's longterm electricity generation pathways", Energy Strateg. Rev., vol. 17, pp. 6-18, 2017.

[13] A. Malik, "How Pakistan is coping with the challenge of high oil prices", Pak. Dev. Rev., vol. 46, no. 4, 2007.

[14] A. H. Abbasi, F. Mahmood, M. Kamal, A. Baig, "Pakistan Energy Vision 2035", Sustain. Dev. Policy Inst., pp. 7-8, 2014.

[15] UNEP, "United Nations Environment Program", UNEP, 2020. [Online]. Available at: https://www.thebalancesmb.com/what-issustainability-3157876.

[16] Z. yu Zhao, H. Yan, "Assessment of the biomass power generation industry in China", Renew. Energy, vol. 37, no. 1, pp. 53-60, 2012.

[17] Y. Lei, "SWOT analysis for the development of photovoltaic solar power in Africa in comparison with China", Environ. Impact Assess. Rev., vol. 77, no. April, pp. 122-127, 2019.

[18] X. Shi, "The future of ASEAN energy mix : A SWOT analysis", Renew. Sustain. Energy Rev., vol. 53, pp. 672-680, 2016.

[19] B. Cayir Ervural, S. Zaim, O. F. Demirel, Z. Aydin, D. Delen, "An ANP and fuzzy TOPSIS-based SWOT analysis for Turkey's energy planning", Renew. Sustain. Energy Rev., vol. 82, no. April 2016, pp. 1538-1550, 2018.

[20] Y. Khalil, "Strengths , Weaknesses , Opportunities , and Threats ( SWOT) Analysis of Fission Nuclear Power for Electricity Generation」, no. April 2003, 2017.

[21] C. Fertel, O. Bahn, K. Vaillancourt, J. P. Waaub, "Canadian energy and climate policies: A SWOT analysis in search of federal/provincial coherence", Energy Policy, vol. 63, pp. 1139-1150, 2013.

[22] F. A. Ishola, O. O. Olatunji, O. O. Ayo, S. A. Akinlabi, P. A. Adedeji, A. O. Inegbenebor, "Sustainable nuclear energy exploration in Nigeria - A SWOT analysis, Procedia Manuf., vol. 35, pp. 1165-1171, 2019.

[23] Y. Wang, L. Xu, Y. A. Solangi, "Strategic renewable energy resources selection for Pakistan: Based on SWOT-Fuzzy AHP approach", Sustain. Cities Soc., vol. 52, no. September 2019, 2020.

[24] M. Kamran, M. R. Fazal, M. Mudassar, "Towards empowerment of the renewable energy sector in Pakistan for sustainable 
energy evolution: SWOT analysis", Renew.

Energy, vol. 146, pp. 543-558, 2020.

[25] S. R. Shakeel, J. Takala, W. Shakeel, "Renewable energy sources in power generation in Pakistan", Renew. Sustain. Energy Rev., vol. 64, no. December 2018, pp. 421-434, 2016.

[26] R. R. R. M. Rooshdi, M. Z. A. Majid, S. R. Sahamir ¿N. A. A. Ismail, "Relative importance index of sustainable design and construction activities criteria for green highway", Chem. Eng. Trans., vol. 63, no. 2007, pp. 151-156, 2018.

[27] US EPA, "Global Greenhouse Gas Emissions Data", US EPA, 2010. [Online]. Available at: https://www.epa.gov/ghgemissions/globalgreenhouse-gas-emissions-data.

[28] World Bank, "International Energy Agency (IEA)", IEA, 2017. [Online]. Available at: http://www.iea.org. 